\title{
PENGARUH PRODUCT PLACEMENT VOLVO DI DALAM FILM TWILIGHT SAGA: BREAKING DAWN PART 1 \& PART 2 TERHADAP BRAND RECALL
}

\author{
Ghygha Yunus Widya Prasetya \\ Fakultas Ekonomi Universitas Ma Chung \\ E-mail: Ghygha.6164@gmail.com
}

\begin{abstract}
Movie scenes have become attractive means for many industries to present their products without enforced impression. Through careful designed product placement strategy, Twilight movie became the perfect promotional media for Volvo in promoting their products. Volvo is one of the premium automotive brands under the auspices of Indomobil. This well-known brand always put and positions their product merely for the target premium. Product placement is an example of a hybrid message or an attempt to influence audience at an affordable cost. Some benefits in advertising through product placement are a lot of audiences see the products so that the brand awareness and the products' credibility would significantly increase. In conclusion, consumer's behavior in recognizing and remembering a product might be affected by their vision, hearing, and admiration.
\end{abstract}

Keywords: Product Placement, Volvo, Twilight Saga, Breaking Dawn, Brand Recall

\begin{abstract}
Abstrak
Penempatan produk ke dalam adegan film dapat ditampilkan sedemikian rupa sehingga tidak terlihat seperti dipaksakan yaitu menggunakan strategi product placement. Salah satu product placement yang sering muncul didalam film ini adalah Volvo. Volvo merupakan merek premium yang berada di bawah naungan Indomobil. Volvo merupakan salah satu pemain dari industri otomotif yang menempatkan dan memposisikan brand mereka hanya untuk target premium. Product placement merupakan suatu contoh dari hybrid message atau upaya untuk mempengaruhi audience yang dilakukan dengan biaya tertentu, namun tidak teridentifikasi sebagai biaya sponsor yang sangat mahal. Selain banyak dilihat oleh audience keuntungan dari Volvo dalam beriklan melalui product placement ini adalah dengan menampilkan produk tersebut dalam film, maka brand awareness, dan kredibilitas dapat ditingkatkan secara signifikan. Sehingga dapat disimpulkan bahwa perilaku konsumen dalam mengenal dan mengingat suatu produk itu dapat dipengaruhi oleh apa yang dia lihat, dengar dan kagumi.
\end{abstract}

Kata kunci: Product Placement, Volvo, Twilight Saga, Breaking Dawn, Brand Recall

Berkembangnya film di Hollywood dan pendistribusian film di kancah internasional menjadikan penempatan produk dalam film sebagai media yang dapat mempengaruhi 
konsumen. Penempatan produk ke dalam adegan film dapat ditampilkan sedemikian rupa sehingga tidak terlihat seperti dipaksaan yaitu menggunakan strategi product placement.

Product placement dapat menjadi sebuah alternatif beriklan yang efektif. Karena sebuah film layar lebar akan diputar di bioskop dan memiliki audience yang cukup banyak, apalagi jika film tersebut sukses. Selepas di putar di layar lebar, film tersebut memiliki kesempatan untuk ditayangkan di televisi dan kemudian dirilis dalam bentuk VCD dan DVD. Artinya iklan product placement akan dilihat terus setiap kali filmnya ditonton.

Film yang bagus diharapkan mampu merangsang perhatian yang tinggi dari audience yang menonton film tersebut. Perhatian yang tingi terhadap film tersebut diharapkan akan dapat mendorong awareness yang tinggi pula terhadap suatu produk yang ditampilkan dalam film. Film-film yang sukses atau biasa kita sebut film box office biasanya memiliki lifespan yang sangat lama, mulai dari pemutaran film di bioskop, beredarnya VCD dan DVD film tersebut hingga pemutarannya di televisi yang dapat terjadi berulang-ulang. Hal tersebut membuat product placement yang ada di dalam film dapat terlihat oleh audience dalam jumlah yang cukup dan lebih dari sekali terjadi pengulangan, sehingga exposure yang dihasilkan akan sangat besar dan diharapkan memiliki efektifitas yang cukup besar juga dalam menimbulkan awareness akan suatu produk.

Salah satu contoh film Box Office yang sukses adalah Breaking Dawn part 1 \& part 2. Dimana sebuah film roman fantasi yang disutradarai oleh bill condon dan diangkat dari novel Breaking Dawn karangan Stephenie Meyer dan film ini merupakan bagian dari film terakhir seri the Twilight Saga. Film Breaking Dawn part 1 \& part 2 ini tergolong sukses dalam peluncuran perdananya pada tahun 2011 untuk Breaking Dawn part 1 dan Breaking Dawn part 2 pada tahun 2012. hal ini terlihat dalam perolehan pendapatan sekitar US\$ 141,3 juta (Rp 1,3 triliun) di AS dan Kanada serta US\$ 340,9 juta (Rp 3,2 triliun) untuk total pemutaran di seluruh dunia dalam kurun waktu 1 minggu (http:// www.suara-pembaruan.com diakses tanggal 11 oktober 2013 ). Film ini juga berhasil menduduki peringkat delapan dalam deretan film dengan perolehan tertinggi pada pekan perdananya.

Salah satu product placement yang sering muncul didalam filmini adalah Volvo. Hal ini terlihat bahwa produk Volvo di setiap sekual dari Breaking Dawn selalu muncul dengan beberapa varian produk yang dimiliki. Mulai dari sekual awal produk Volvo telah digunakan dalam kendaraan oleh pemeran utama hingga di sekual terakhir pun masih menjadi kendaraan pribadi yang di dalam ceritanya menjadi milik tokoh utama dalam Breaking Dawn part 2. Pada film Breaking Dawn part 2 di sini dapat terlihat kemunculan produk Volvo dengan tipe yang masih tergolong tipe terbaru yaitu Volvo S60 R-Design, dimana kemunculan produk Volvo yang satu ini termasuk jelas antara produk dan merek yang ditampilkan dalam beberapa adegan yang dipakai oleh pemeran utama di dalam film tersebut.

Berdasarkan data dan keterangan tersebut penulis ingin melihat dan mengetahui seberapa besar pengaruh product placement yang ada di dalam film Breaking Dawn Part $1 \&$ Part 2 terhadap brand recall Volvo. 
Faktor-faktor yang Mempengaruhi Kinerja.... (Winarti, Sukisno S. R., Yana U.)

\section{Product Volvo}

Volvo dalam bahasa latin yang berarti "saya berputar", merupakan bentuk lain dari kata "volvere", nama Volvo untuk pertama kalinya didaftarkan pada mei 1911 sebagai perusahaan yang bernaung di bawah SKF AB dan sebagai merek dagang yang direncanakan akan digunakan untuk bearing seri khusus. Perusahaan AB Volvo tidak tidak punya kegiatan apa-apa hingga 10 agustus 1926, manajer penjualan, Assar Gabrielsson, and insinyur, Gustav Larson, membentuk AB Volvo sebagai perusahaan pembuat mobil yang bernaung di bawah SKF Grub hanya dengan persiapan selama setahun.(http://dunia-otomotif.blogspot.com diakses tanggal 11 oktober 2013). Seri mobil Volvo yang pertama kali diproduksi adalah Volvo OV 4 keluar dari pabrik 14 april 1927 dan tanggal ini menjadi tanggal resmi berdirinya Volvo.

Di Indonesia Volvo merupakan merek premium yang berada di bawah naungan Indomobil sejak tahun 1984. Volvo merupakan merek yang disegani pada saat Volvo baru memasuki pasar Indonesia karena modelnya yang ekslusive dan elegan pada masa itu, sehingga dapat menarik perhatian para anggota pemerintahan. Akan tetapi seperti kebanyakan perusahaan lainnya, Volvo tidak dapat bertahan ketika menghadapi krisis multidimensional yang melanda Indonesia pada tahun 1998.

Volvo pada tahun 1986 memiliki 2 tipe mobil yaitu 244GL dan 340 DL. Pada tahun 1990 Volvo menambah varian mobilnya yaitu tipe 240 GL, 740 GL dan 960 GL. Pada tahun 1995 Volvo menambah variannya lagi yaitu tipe S70 dan 960GL. Pada tahun 2000 Volvo menambah variannya lagi yaitu tipe 960GL, S/V 70, S80 series dan S90. Pada tahun 2005 akhirnya Volvo menambah varian yaitu tipe S40,S60 2.0,S60 2.3, S60 2.3, dan S80 2.4. (http://dunia-otomotif.blogspot.com diakses pada tanggal 11 oktober 2013).

Volvo merupakan salah satu pemain dari industri otomotif yang menempatkan dan memposisikan brand mereka hanya untuk target premium dan Volvo tidak tergiur dengan para pemain lain yang mengikuti perkembangan di Indonesia dengan menyesuaikan diri membuat produk untuk pasar menengah dan menengah kebawah ataupun tipe mobil lain. Volvo meupakan brand otomotif yang memberikan kesan exclusive dan elegance, serta termasuk raksasa otomotif kelas atas pada jamannya. Volvo tetap konsisten pada segemen premium dan terus berada dalam kelas mobil sedan. Volvo dahulu menjadi mobil pilihan pemerintah untuk dijadikan mobil kenegaraan pada tahun 1990-an karena Volvo merupakan brand yang paling mengutamakan keamanan di bandingkan dengan brand lainnya.

\section{Product Placement Volvo}

Selain menggunakan iklan di televisi, dan media online Volvo juga menggunakan film untuk mengiklankan produknya yang dikenal product placement. Product Placement merupakan sebuah cara untuk meningkatkan promosi sebuah produk atau jasa dengan menampilkan produknya sehingga menimbulkan kesan bahwa keberadaan produk tersebut seolah-olah menjadi bagian dari cerita film (Belch,2012). Product placement juga merupakan istilah yang sama dengan brand placement dalam literatur pemasaran dan periklanan (Hornick,2006). 
Volvo ingin mencoba untuk beriklan melalui product placement karena dengan menggunakan product placement pesan yang ingin disampaikan lebih efektif dan langsung mengenai target audience yang diharapkan (Moser, Bryant and Sylvester, 2006). Pada dasarnya konsep product placement hampir sama dengan stretegi sponsorship akan tetapi yang membedakan adalah keberadaan produk tersebut tidak disebutkan sebagai sponsor melainkan sebagai bagian dari alur / property film tersebut.

Product placement merupakan suatu contoh dari hybrid message atau upaya untuk mempengaruhi audience yang dilakukan dengan biaya tertentu, namun tidak teridentifikasi sebagai biaya sponsor yang sangat mahal ( Balasubramanian et al, 2006). Selain itu product placement juga unggul dalam mempersuasi permirsa dalam hal brand recall, asosiasi merek, sikap terhadap pesan komersial dan merek, serta intensi.(Bhatnagar,2002).

Volvo mempromosikan produknya dengan cara product placement untuk membatu mengenalkan dan memasarkan produknya, melihat penjulan Volvo semakin tahun semakin menurun. Hal ini dapat terlihat dalam grafik penjulan Volvo berikut.
Berdasarkan data tersebut terlihat mulai tahun 2005 sampai tahun 2010 penjualan Volvo menurun, dan di awal tahun 2011 penjualan Volvo kembali meningkat. Mengingat pada waktu itu film Breaking Dawn part 1 menduduki peringkat pertama box office dunia di tayangan perdananya. Melihat akan hal itu maka pihak Volvo tetap akan mempromosikan produknya melalui product placement didalam film Breaking Dawn Part 2. Jadi secara tidak langsung produk Volvo juga sudah dilihat dan dikenal lebih dari jutaan audience di dunia semenjak film Breaking Dawn part 1 diputar di bioskop, itu belum juga audience yang melihat dari DVD bajakan yang beredar di pasaran dan di Youtube.

Selain banyak dilihat oleh audience keuntungan dari Volvo dalam beriklan melalui product placement adalah dengan menampilkan produk tersebut, maka brand awareness, dan kredibilitas dapat ditingkatkan secara signifikan. Juga dapat memperkuat citra merek. Dari sisi audience dalam hal ini didampingi untuk mengidentifikasi dan menghubungkan dirinya dengan lingkungan yang digambarkan atau dengan selebritis yang menggunakan produk Volvo tersebut (fill, 2006). Dari sisi biaya, biaya penggunaan product place-

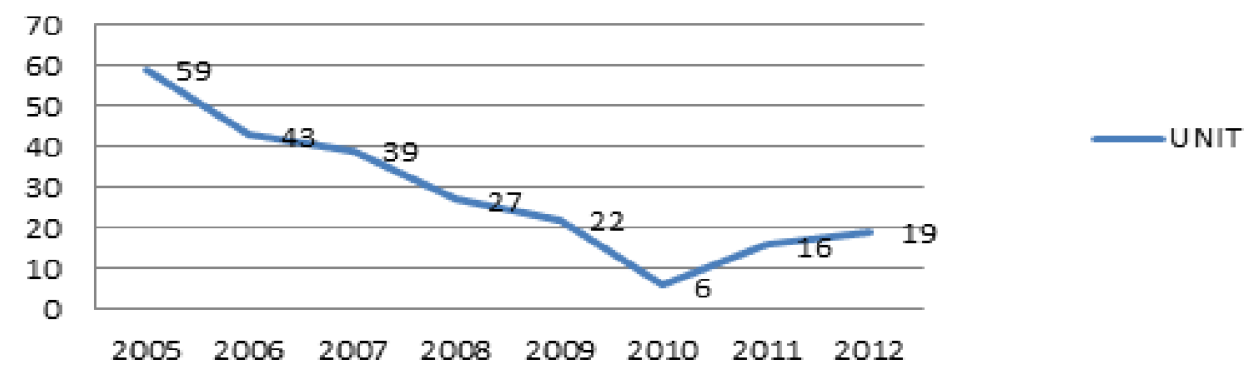

Source: http://gaikindo.or.id diakses tanggal 11 oktober 2013

Gambar 1. Perkembangan Penjualan Volvo 
Faktor-faktor yang Mempengaruhi Kinerja.... (Winarti, Sukisno S. R., Yana U.)

ment ini mulai dari gratis sampai jutaan dollar per produk. Namun dengan biaya termahal sekalipun perusahaan seperti Volvo masih tetap mengalami keuntungan, dengan tingginya tingkat exposure yang dihasilkan.

\section{Penutup}

Berdasarkan study tentang product placement tersebut maka dapat dikatakan bahwa Volvo termasuk dalam contoh produk yang sukses dalam menggunakan Strategi Product Placement, Hal ini dapat dilihat dari penjualan Volvo yang meningkat pada saat film Breaking Dawn ditayangkan di bioskop seluruh dunia.

Hal tersebut tidak menutup kemungkinan dikarenakan film Breaking Dawn pada saat itu menjadi film box office sehingga banyak audience penasaran ingin melihat. Sehingga pada saat itu dalam kurun waktu 1 minggu saja. Penonton dari Breaking Dawn sudah mencapai jutaan penonton. Dengan demikian maka semakin banyak orang yang melihat Breaking Dawn maka semakin banyak juga yang melihat dan mengenal produk Volvo ini.

Dengan melihat produk Volvo di dalam film ini maka, image dari produk Volvo ini juga akan meningkat sehingga orang-orang yang mengidolakan artis dan film ini juga akan mengenal dan apabila ekonominya mencukupiakan membeli mobil
Volvo ini. Selain itu apabila orang tersebut melihat mobil Volvo maka yang terbayang dibenaknya adalah mobil yang ada di film Breaking Dawn. Sehingga dapat disimpulkan bahwa perilaku konsumen dalam mengenal dan mengingat suatu produk itu dapat dipengaruhi oleh apa yang dia lihat, dengar dan kagumi.

\section{DAFTAR PUSTAKA}

Balasubramanian, S. K., Karrh, J. A. \& Patwardhan, H. 2006. Audience Response to Product Placement: an Integrative Framework \& Future Research Agenda. Journal of Advertising, Fall, 35,3 .

Belch, G.B. 2012. Advertising an promotion: An Integrated Marketing Communication Perspective. Mc Graw Hill. New York.

Fill, C. 2006. Marketing CommunicationsEnga-gement, Strategies \& Practice 4th Ed. FT- Prentice Hall Financial Times.

Hornick, L. 2006. The Evolution of product placement: Consumer Awareness and Ethical Cosideration. West Virginia University. 
